\title{
PENGARUH UMPAN TETAP DAN UMPAN BERUBAH TERHADAP AKURASI SMASH DALAM PERMAINAN BULUTANGKIS SMK PENERBANGAN SINGOSARI 2016/2017
}

\author{
Dwi Aji Prasojo ${ }^{1)}$, Alfian Yahya ${ }^{2)}$ \\ SMK Penerbangan Singosari Malang \\ email: ${ }^{1}$ Dwi.ajiprasojo@gmail.com \\ IKIP Budi Utomo Malang \\ email: ªlfianyahya23@yahoo.com
}

\begin{abstract}
ABSTRAK
Penelitian ini merupakan penelitian eksperimen. Rancangan atau desain yang digunakan eksperimen 1 dan eksperimen 2 dengan pola one group pretest and posttesdesign. Dalam penelitian ini, jumlah sampel penelitian diambil dari seluruh populasi, yaitu 15 kelompok eksperimen 1 dan 15 kelompok eksperimen 2 dengan jumlah 30 siswa. Berdasarkan perhitungan hasil analisis data, dapat dikemukakan kesimpulan, bahwa: (1) Ada pengaruh latihan umpan tetap terhadap akurasi forehand smash. Hal ini terbukti berdasarkan hasil kelompok eksperimen nilai ttes $=9,556>$ ttabel $=2,145$, (2) Ada pengaruh latihan umpan berubah terhadap akurasi forehand smash. Hal ini terbukti berdasarkan nilai kelompok eksperimen nilai tes $=15,877>$ ttabel $=2,145$, (3) Ada perbedaan antara pengaruh latihan umpan tetap dan latihan umpan berubah terhadap peningkatan akurasi forehand smash hal tersebut terbukti nilai uji-t beda mean t-test $=25,65$, sedangkan nilai t-tabel adalah adalah ts0,95 = 1,70 dan ts0,99 =2,47 dengan d.b. 28. Dari hasil analisis data di atas, diketahui bahwa nilai ttest $=25,65>$ nilai ts $0,95=1,70$ dan ts $0,99=2,47$.
\end{abstract}

Kata kunci :Umpan tetap, Umpan Berubah dan Akurasi Smash.

\begin{abstract}
This research is an experimental research. The design or design used in experiment 1 and experiment 2 with the pattern of one group pretest and posttes design. In this study, the number of research samples was taken from the entire population, namely 15 experimental groups 1 and 15 experimental groups 2 with a total of 30 students. Based on the calculation of the results of data analysis, conclusions can be expressed, that: (1) There is the effect of fixed feed training on forehand smash accuracy. This is proven based on the results of the experimental group the value of ttes $=9.556>t$ table $=2.145$, (2) There is the effect of the feed training to change for the forehand smash accuracy. This is proven based on the experimental group value of the test value $=15.877>t$ table $=2.145$, (3) There is $a$ difference between the effect of the fixed feed training and the change in the feed training to increase the forehand smash accuracy. 65, while the t-table value is ts $0.95=1.70$ and ts0.99 $=2.47$ with $d b 28$. From the results of the data analysis above, it is known that the value of ttest $=25.65>$ the value of $t 50.95=1.70$ and $t s 0.99=2.47$.
\end{abstract}

Keywords:Fixed feed, Changed Feed and Smash Accuracy.

DWI AJI. Pengaruh Umpan Tetap Dan Umpan Berubah Terhadap Akurasi Smash Dalam Permainan Bulutangkis Smk Penerbangan Singosari 2016/2017 


\section{PENDAHULUAN}

Badminton bukanlah berasal dari inggris. Bukti-bukti sejarah justru menunjukkan bahwa di india pertama kali peraturan permainan olahraga ini ditulis sekitar tahun 1870-an (Alhusni Syahri, 200). Untuk menjadi pemain bulutangkis yang baik perlu berbagai macampersyaratan, salah satunya adalah tehnik dasar permainan bulutangkis. Dalamcabang olahraga bulutangkis terdapat berbagai teknik dasar, diantaranya service,smash, lob, dropshoot, dan gerak kaki. Sebagaimana di kemukakan oleh poolebahwa "ketrampilan dasar bulutungkis dapat dibagi dalam lima bagian yaitu 1.)service 2.) smash 3.)overhead 4.) drive 5.) drop" (Sumarno, 2007). Kelima teknik dasar permainan bulutangkis tersebut harus dikuasai oleh pemainbulutangkis untuk menunjang atau mencapai tujuan permainan.

Pukulan smash merupakan pukulan kunci untuk mematikan permainan4 lawan, kesempurnaan pukulan lainnya tidak berarti bila tidak di lengkapi dengan pukulan smash. Pukulan lainnya sesungguhnya hanya berfungsi untuk membuka daerah serangan,mengacaukan posisi lawan dan untuk membuat suatu kesalahan.Dan perlu diketahui bahwa pukulan smash seringkali memberikan hasil yang baik bagi pemain bulutangkis. Hal ini tidak mengherankan pukulan smash itu sendiri dapat mematikan pola permainan lawan untuk menghasilkan angka atau pointm. Smash adalah pukulan yang dilakukan, paling cepat dan sekeras-kerasnya,menukik dan masuk kelapangan (Sumarno, 2007). Gerakan awal dari dari pelaksanaan pukulan smash adalah bagaiman membangkitan tenaga otot-otot yang menggekan kaki, tubuh, pundak, siku, dan pergerakan tangan. Koordinasi gerakan ini merupakan gerakan terpadu yang berakhir pada lecutan pergelangan tangan untuk melepaskan pukulan sesuai dengan apa yang dihendaki. Gerakan yang dilakukan secara berkesinambungan dan teratur. Pola gerakan tersebut apabila telah dikuasai dengan baik, akan menjadi pola gerak serempak dan berulang secara otomatis.

Dalam melakukan smash posisi pemain terhadap bola/shuttlecock sangat penting. Oleh karena itu pemain harus bergerak cepat untuk menuju ketempatbola datang pada saat yang tepat, sehingga pemain dapat memukul bola shuttlecock dalam sikap yang tenang dan dapat mengarahkan bola kearah sasaran yang tepat. Kedudukan bola/ shuttlecock ketika akan di pukul harus berada diataskepala agak kedepan, sehingga dalam mengayunkan raket perkenaannya tegaklurus antara datangnya bola/shuttlecock dengan raket. DWI AJI. Pengaruh Umpan Tetap Dan Umpan Berubah Terhadap Akurasi Smash Dalam Permainan Bulutangkis Smk Penerbangan Singosari 2016/2017 
Pukulan dilakukan dengan menghujamkan bola/shuttlecock secara keras dan curam dengan arah tegak lurus menyilang akan menghasilkan pukulan yang sullit ditebak arahnya, sehingga sering menggingungkan lawan.

Untuk memperoleh pukulan smash yang baik dalam permainan bulutangkis harus dilatih dan dibina sejak awal, mulai dari bagai mana berdiri pada posisi siap, bergerak melangkah dan pada saat memukul. Jenis latihan harus dirancang dengan baik sesuai dengan unsur gerak yang terdapat dalam permainan bulutangkis. Selanjutnya dibuat bentuk latihan untuk dipraktekan dalam suatu rangkaian yang sistematis. Dan diperlukannya suatu metode yang tepat, juga dibutuhkan adanya keseriusan dan keuletan dalam melakukan metode melatih yang perlu dikembangkan dalam memberikan latihan teknik pukulan smash Gerak awal didalam melakukan pukulan smash hampir sama dengan pukulan lob. Perbedaan yang utama adalah pada saat akan memukul yaitu pada pukulan lob bola/shuttlecock diarahkan tajam kebawah, dengan kecepatan tinggi karena menggunakan tenaga yang sepenuhnya dan lecutan pergerakan tangan (Tohar, 1992).

(Suhendro, 2007) mengemukakan bahwa, "Latihan merupakan proses kerja yang sisematis, dan dilakukan secara berulang-ulang dengan beban latihan yang meningkat". Menurut (Harsono, 1988),"Yang dimaksud dengan sistematis adalah berencana, menurut jadwal, menurut pola dan sistem tertentu, metodis, dari mudah ke sukar, latihan yang teratur, dari sederhana ke yang lebih kompleks". "Latihan harus dilakukan secara berulang-ulang, maksudnya latihan harus dilakukan minimal tiga kali dalam seminggu. Dalam pengulangan ini diharapkan gerakan yang pada saat awal latihan dirasakan sukar dilakukan, pada tahap-tahap berikutnya akan menjadi lebih mudah dilakukan" (Suhendro, 2007).

(Sajoto, 1988) mengemukakan, "Kondisi fisik adalah salah satu prasyarat yang sangat diperlukan dalam setiap usaha peningkatan prestasi seorang atlit, bahkan dapat dikatakan dasar landasan titik tolak suatu awalan olahraga prestasi".

Berdasarkan latar belakang masalah dan judul di atas maka rumusan masalah yang disusun dalam penelitian ini adalah sebagai berikut : 1) Adakah pengaruh latihan umpan tetap terhadap akurasi forehand smash dalam permainan bulu tangkis? 2) Adakah pengaruh latihan umpan berubah terhadap akurasi forehand smash dalam permainan bulu tangkis? Adakah perbedaan pengaruh latihan umpan tetap dan umpan berubah terhadap akurasi forehand smash dalam permainan bulu tangkis?.

DWI AJI. Pengaruh Umpan Tetap Dan Umpan Berubah Terhadap Akurasi Smash Dalam Permainan Bulutangkis Smk Penerbangan Singosari 2016/2017 


\section{METODE}

Sesuai dengan tujuan penelitian yaitu untuk mengetahui pengaruh latihan umpan tetap dan umpan berubah terhadap kemampuan akurasipukulan smash terhadap siswa pada permainan bulutangkis siswa ektrakulikuler SMK Penerbangansingosari pada tahun 2016/2017 maka metode yang digunakan adalah metode eksperimen. Sedangkan bentuk rancangan penelitian yang digunakan adalah one-group pretest-postest design (Sugiyono, 2011) yaitu dengan menggunakan satu subyek yang diberi dua macam perlakuan. Adapun gambaran rancangan penelitian ini adalah sebagai berikut:

$\mathrm{O} 1=$ nilai pretest $($ sebelum dikasih diklat)

$\mathrm{O} 2$ =nilai postest $($ setelah dikasih diklat)

Pengaruh diklat terhadap prestasi kerja

\section{$\mathrm{O}_{1} \times \mathrm{O}_{2}$}

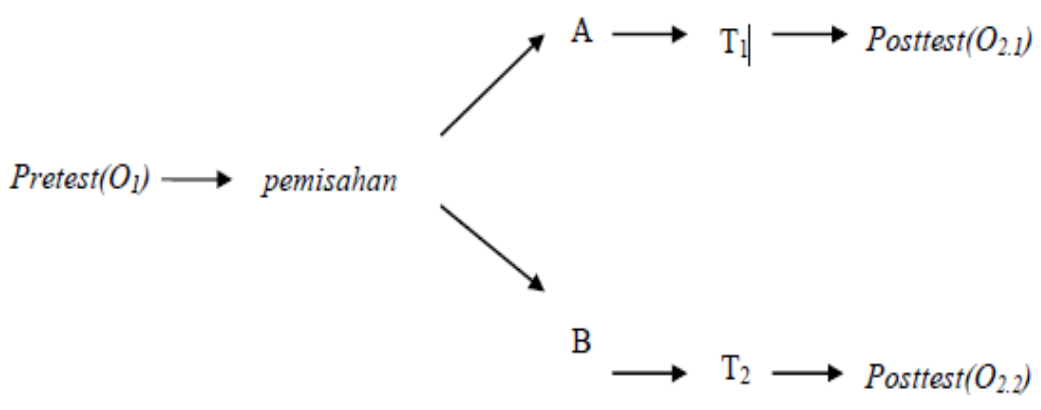

\section{Tabel 1 Skema Rancangan Penelitian}

(Sugiyono, 2011)

Pretest : Tes Awal

A : Kelompok Eksperimen Latihan Umpan tetap

B : Kelompok Eksperimen Latihan Umpan berubah

T1 : Perlakuan Latihan Umpan tetap

T2 : Perlakuan Latihan Umpan berubah

Posttest : Tes Akhir

Sedangkan populasi dalampenelitian ini adalah siswa ektrakulikuler SMK Penerbangan Singosaritahun pelajaran 2017/2018 yang berjumlah 30 orang.Penelitian ini membagi menjadi 2 kelompok menggunakan pola Matchig Subject (M-S) dengan rumus A-B-B-A. Sebelum dibagi, sampel DWI AJI. Pengaruh Umpan Tetap Dan Umpan Berubah Terhadap Akurasi Smash Dalam Permainan Bulutangkis Smk Penerbangan Singosari 2016/2017 
melakukan Pretest Kemampuan smash pada permainan bulu tangkis, selanjutnya siswa dibagi menjadi dua kelompok secara acak sesuai nomer urutTeknik pengumpulan data yang digunakan dalam penelitian inimmenggunakan teknik eksperimental (latihan umpan tetap dan umpan berubah) dan melakukan test awal yang diadakan sebelum diberi perlakuan dan test akhir yang diadakan setelah mendapat perlakuan. Pengumpulan data dibagi mejadi 2 tahap yaitu tahap persiapan dan tahap pelaksanaan.

Data-data yang diperoleh dari hasil tes akan dianalisis menggunakan teknik analisis data untuk mengetahui ada tidaknya pengaruh yang signifikan terhadap peningkatan kemampuan smash menggunakan teknik analisis uji beda(uji-t).Metode menjelaskan paparan dalam bentuk paragraf tentang rancanganpenelitian,sumberdata,teknikpengumpulandata,dananalisisdatayan g secaranyatadilakukanpeneliti,denganpersentase.

\section{HASILDANPEMBAHASAN}

Berdasarkan data penelitian yang telah didapatkan dan hasilpenghitungan data, maka dapat disimpulkan, sebagai berikut:

1. Ada pengaruh latihan umpan berubah terhadap kemampuan akurasi pukulan smash pada siswa ekstrakulikuker SMK Penerbangan Singosari Tahun Pelajaran 2016/2017. Terbukti dari hasil penghitungan melalui uji-t didapatkan nilai ttes penelitian sebesar 15,877> ttabel $=2,131$ pada taraf signifikansi 5\% dan d.b. sebesar 14 .

2. Ada pengaruh latihan umpan tetap terhadap peningkatan kemampuan kemampuan akurasi pukulan smash pada siswa ekstrakulikuker SMK Penerbangan Singosari Tahun Pelajaran 2016/2017. Terbukti dari hasil penghitungan melalui uji-t didapatkan nilai ttes penelitian sebesar 9,556 > ttabel = 2,131 pada taraf signifikansi 5\% dan d.b. sebesar 14 .

3. Ada perbedaan antara pengaruh latihan umpan tetap dan latihan umpan berubah terhadap peningkatan kemampuan akurasi pukulan smash pada siswa ekstrakulikuker SMK Penerbangan Singosari Tahun Pelajaran 2016/2017. Hal tersebut dibuktikan dengan nilai ttest $=25,65$ sedangkan nilai ttabel adalah ts $0,95=1,70$ dan ts $0,99=2,47$ dengan d.b. 28 dari hasil analisisi data di atas diketahui bahwa nilai ttest $=25,65>$ nilai ts $0,95=1,70$ dan ts $0,99=2,4$

Hasil penelitian berisi paparan hasil analisis yang berkaitan dengan pertanyaan penelitian, sedangkan pembahasan berisi pemaknaan hasil dan 
perbandingan dengan teori dan atau hasil penelitian sejenis,dengan persentase 40-60\% dari keseluruhan artikel. Hasil penelitian dapat dilengkapi dengan tabel, grafik (gambar), dan atau bagan. Kemungkinan tindak lanjut kegiatan dapat juga disampaikan pada bagian ini

\section{Tabel 1. Hasil Analisis Beda Mean Posttest Kedua Kelompok}

\section{Eksperimen Dan Kontrol}

\begin{tabular}{|c|c|c|c|c|c|}
\hline \multirow[b]{2}{*}{ Uraian } & \multirow{2}{*}{$\begin{array}{l}\text { Rata- } \\
\text { rata }\end{array}$} & \multirow[b]{2}{*}{ t-tes } & \multirow[b]{2}{*}{ d.b. } & \multicolumn{2}{|c|}{$t_{\text {tabel }}$} \\
\hline & & & & $\begin{array}{c}\text { Trf. Sig } \\
0,95 \%\end{array}$ & $\begin{array}{l}\text { Trf Sig } \\
0,99 \%\end{array}$ \\
\hline Posttest $\mathrm{X}_{1}$ & 78,8 & \multirow[t]{2}{*}{25,65} & \multirow[t]{2}{*}{28} & \multirow[t]{2}{*}{1,70} & \multirow[t]{2}{*}{2,47} \\
\hline Posttest $\mathrm{X}_{2}$ & 70,6 & & & & \\
\hline
\end{tabular}

\section{SIMPULAN}

Berdasarkan data hasil penghitungan dengan teknik statistik melalui pengaplikasian rumus uji-t, diketahui kelompok latihan berubah nilai ttes $(15,877)>$ ttabel $(2,048)$ pada taraf signifikansi 5\% dan d.b. sebesar 28, dan kelompok latihan umpan tetap nilai ttes $(9,556)>$ ttabel $(2,048)$ pada tarafsignifikansi 5\% dan d.b. sebesar 28. Dengan demikian bahwa hipotesis nihil

(Ho) ditolak, sedangkan hipotesis alternative (Ha) diterima, yang berbunyi "ada pengaruh latihan umpan tetap dan latihan umpan berubah terhadap Terhadap Kemampuan akurasi pukulan Smash Bulu Tangkis Ektrakurikuler SMK Penerbangan Singosari 2016/2017" diterima. 


\section{DAFTARPUSTAKA}

Alhusin, Syahri. 2007. Gemar Bermain Bulutangkis. Surakata : Fakultas Ilmu Keolahragaan Universitas Negeri Yogyakarta.

Arikunto, Suharsimi. 2010 . ProsedurPenelitian Suatu Pendekatan Praktik. Jakarta: Rineka cipta.

Sajoto, M. 1988. Pembinaan Kondisi Fisik Dalam Olahraga. Jakarta: Departemen Pendidikan dan Kebudayaan Direktorat Jendral Pendidikan Tinggi Proyek Pengembangan Lembaga Pendidikan Tenaga Kependidikan.

Sugiyono. 2011. Metode Penelitian Pendidikan Pendekatan kuantitatif kualitatif dan R\&D. Bandung: Alfabeta

Suhendro, Andi. 2007. Dasar-Dasar Kepelatihan. Jakarta: Universitas Terbuka Departemen Pendidikan Nasional.

Sumarnno, T. Muhtar. 2007. Bulu Tangkis (Mata Kuliah Pilihan 1). Jakarta: Universitas Terbuka Departemen Pendidikan Nasional.

M Tohar, 1992. Olahraga Pilihan Bulutangkis. IKIP Semarang. Semarang. 